\title{
VENE KOOLIDE VALMISOLEKUST ÜLEMINEKUKS EESTI ÕPPEKEELEGA GÜMNAASIUMILE 2007. AASTAL
}

\section{Silvi Vare}

Ülevaade. Põhikooli- ja gümnaasiumiseaduse järgi tuleb muukeelsetes gümnaasiumides 2007. aastal üle minna eesti õppekeelele. Ühtlasi nõuab seadus, et selleks ajaks peab koolikorraldus ja riiklik õppekava tagama kõigile muukeelse põhikooli lõpetajatele eestikeelseks õppeks vajaliku keeleoskuse. Artiklis analüüsitakse eesti keele õppe seisu ja riiklikku korraldust vene põhikoolis ning koolilõpetajate eesti keele oskuse taset. Sellega ühenduses käsitletakse koolikorralduslikke muutusi aastatel 1997-2005, sh erinevate keeleõppevormide kasutamist ning vahekorda ja hinnatakse koolide valmisolekut alustada üleminekut eestikeelsele gümnaasiumiõppele. Eraldi vaadeldakse 7 . klassi õpilaste keelelist ettevalmistust, keda 2007. aasta kooliuuendus esimesena puudutab. Artiklis kasutatud haridusstatistika ja sellest tulenevad järeldused peegeldavad olukorda 2004/2005. õppeaastal. Valdkonnaga seonduvaid arenguid on kirjeldatud 2006. aasta veebruarikuu seisuga.

Võtmesõnad: keeleõppe korraldus, kakskeelne haridus, keelekümblus, üleminek eesti õppekeelele

\section{Sissejuhatus}

Eesti riigikeel on eesti keel (PS § 6 ja KS § $1 \lg 1$ ). Sellest tulenevalt on kõigil Eesti püsielanikel, rahvusele ja emakeelele vaatamata, vajadus osata eesti keelt. 2000. a rahvaloenduse andmeil moodustavad muukeelsed inimesed Eesti rahvastikust ligi kolmandiku (32,1\%). ${ }^{1}$ See tähendab riigile tõsist kohustust kanda hoolt selle eest, et kõik ühiskonna liikmed eesti keelt valdaksid. Kõige otstarbekam on seda teha haridussüsteemi kaudu, mis võimaldab järjepidevalt, põlvkondade kaupa ühiskonda keeleliselt kujundada ja inimeste keeleoskust vajalikul viisil arendada. 
Sisuliselt tähendaks see sellist riiklikku hariduskorraldust, kus muukeelne laps omandaks üldhariduse käigus ka eesti kirjakeele. Ehk teisisõnu, eesti keele omandamine oleks kohustusliku põhihariduse loomulik osa. Koolikorraldus peaks tagama niisugusel tasemel eesti keele oskuse, mis võimaldab põhikooli lõpetajal teha vabalt oma edasisi valikuid. Ühtlasi kindlustaks see muukeelsetele lastele eesti lastega võrdsed keelelised võimalused, et oma oskusi, teadmisi ja võimeid realiseerida. Kindla keeleoskustaseme nõuet on võimalik laiendada ka erakoolidele, sest Eesti põhiseaduse järgi (§ $37 \lg 5$ ) on hariduse andmine riigi järelevalve all.

Eestis on praegu võimalik omandada kogu üldharidus ka vene keeles. Põhikooli- ja gümnaasiumiseaduse järgi on aga gümnaasiumiastmes õppekeeleks eesti keel. Et tegelik olukord sellega vastavusse viia, nõuab seadus, et

Riigi- ja munitsipaalgümnaasiumides alustatakse üleminekut eestikeelsele õppele ${ }^{2}$ hiljemalt 2007/2008. õppeaastal. (PGS $1997 \S 52 \lg 2$ )

Ühtlasi nõuab seadus üleminekuks vajalikke ettevalmistustöid põhikoolis:

Muukeelse põhikooli õppekava ja koolikorraldus peavad aastaks 2007 tagama kõigile põhikooli lõpetajatele eesti keele oskuse tasemel, mis võimaldab jätkata õpinguid eesti keeles. (PGS 1997: § $52 \lg$ 1)

Muukeelne põhikool tähendab sisuliselt venekeelset põhikooli, sest emakeelse üldhariduse võimalus on Eestis ainult vene rahvusrühmal.

Haridus- ja Teadusministeeriumi (HTM) andmeil on vene keeles õppijate arv viimaste aastate jooksul oluliselt vähenenud (vt joonis 1), kuid vene kooli õpilased moodustavad üldhariduskoolide õpilastest 2004/2005. õppeaasta seisuga siiski ligi veerandi, 23\% (Ploom 2005: 18, Soll 2005 106).

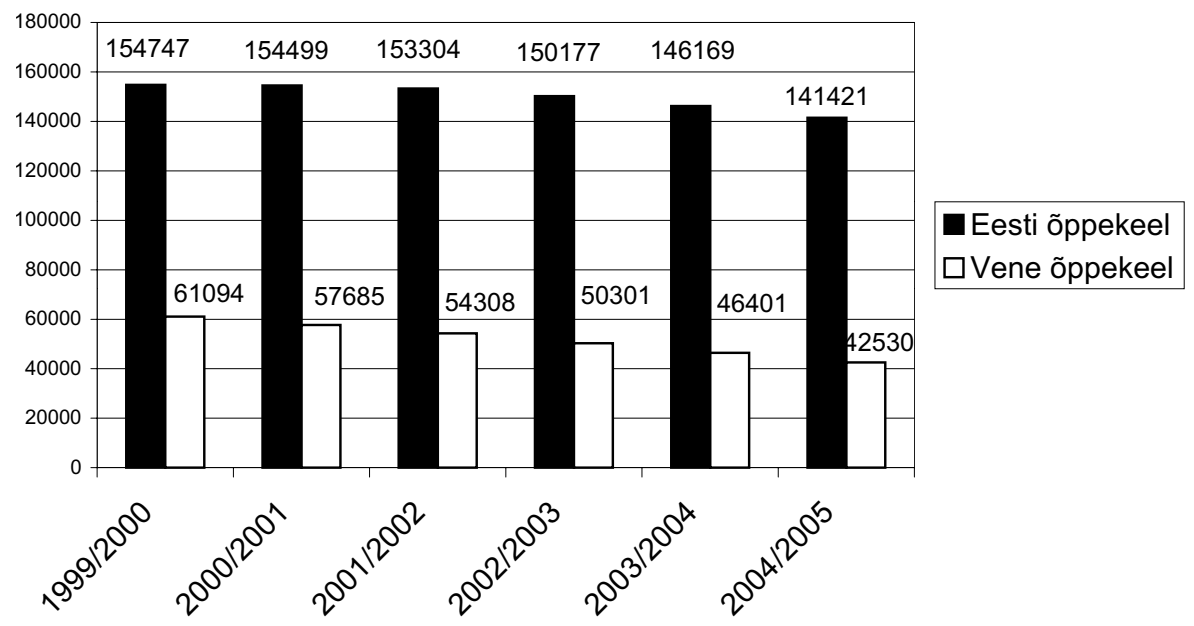

Joonis 1. Õpilaste jagunemine õppekeele järgi 1999/2000-2004/2005. õppeaastal

${ }^{2}$ Vastavalt 2000. a seadusemuudatusele asendati määratlus "eestikeelsele õppele" määratlusega "eesti õppekeelele" (PGS 2000 § 2). 
Koole, kus on võimalik õppida vene keeles, on kokku 102 (tabel 1). Enamikus asuvad need Harju- ja Ida-Virumaal ja vaid väiksel määral mujal maakondades. Vene õppekeelega üldhariduskoole ei ole Saare-, Hiiu- ja Raplamaal.

Vene põhikoolis, mida 2007. a kooliuuendus otseselt mõjutab, õpib 32510 last. Õpilaste jagunemisest klasside kaupa annab ülevaate tabel 2.

Valdav enamik, 80\% vene põhikooli õpilastest on koondunud Tallinnasse ja Ida-Virumaale (vrd joonis 2). Seega oleneb kooliuuenduse teokstegemine eeskätt neist kahest piirkonnast.

Tabel 1. Venekeelset haridust võimaldavad üldhariduskoolid tüüpide kaupa 2004/2005. õppeaastal (Ploom 2005: 20)

\begin{tabular}{|l|c|c|c|}
\hline Õppeasutuse liik & Vene õppekeel & Eesti ja vene õppekeel & Kokku \\
\hline Lasteaed-algkoolid & 4 & - & 4 \\
\hline Põhikoolid & 14 & 21 & 35 \\
\hline Gümnaasiumid & 63 & - & 63 \\
\hline Kokku & 81 & 21 & 102 \\
\hline
\end{tabular}

Tabel 2. Vene õppekeelega põhikooliõpilaste arv klasside kaupa 2004/05. õppeaastal (Reinthal 2005)

\begin{tabular}{|c|c|c|c|c|c|c|c|c|c|}
\hline \multicolumn{1}{|c|}{ Põhikooliõpilaste jagunemine klassiti } \\
\hline I & II & III & IV & V & VI & VII & VIII & IX & kokku \\
\hline 2696 & 2824 & 2871 & 2803 & 3014 & 3699 & 4107 & 5103 & 5393 & 32510 \\
\hline
\end{tabular}

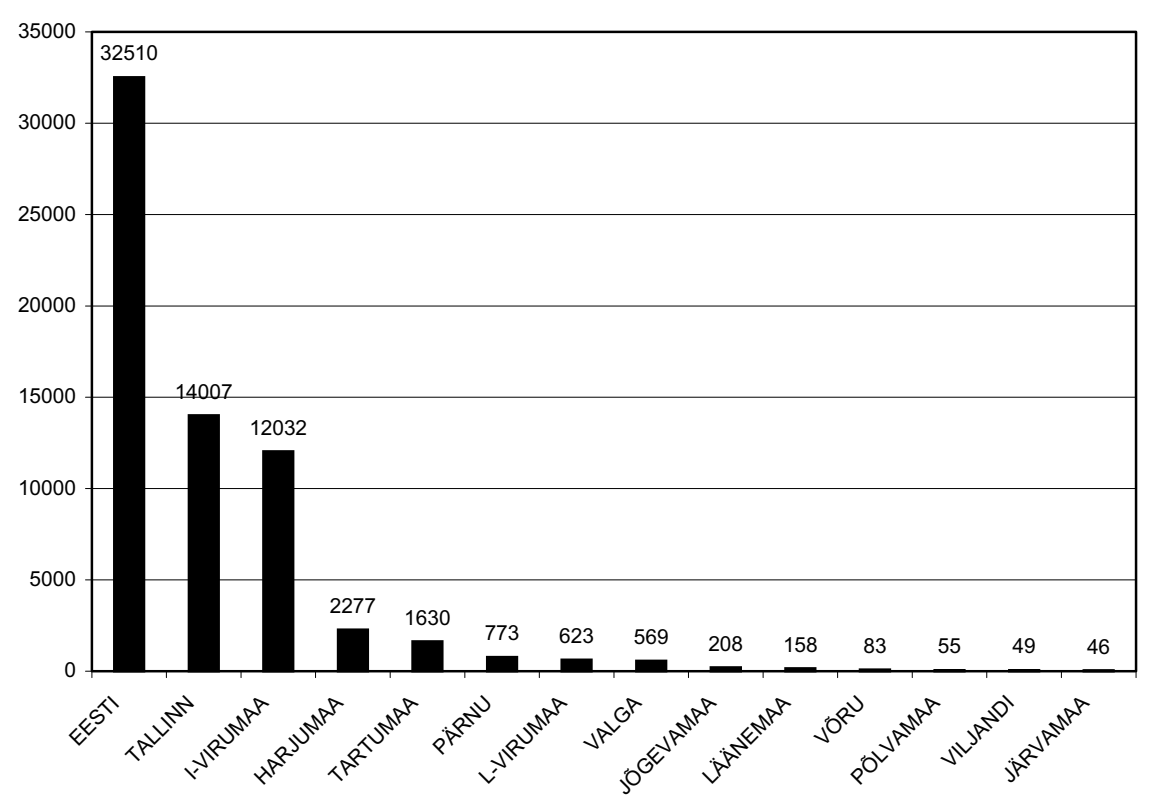

Joonis 2. Vene kooli õpilaste jagunemine piirkonniti (allikas: SA Innove, e-kiri 22.03.2005) 
Järgneva käsitluse eesmärgiks on anda ülevaade sellest, kuidas on edenenud põhikooli- ja gümnaasiumiseaduses 1997. a sätestatud ülesande täitmine, ja hinnata vene õppekeelega koolide valmisolekut minna 2007. a gümnaasiumiastmes üle eestikeelsele õppele. Ehk täpsemalt: kas ja milliseid muudatusi on tehtud koolikorralduses ja õppekavas aastatel 1997-2005 selleks, et tagada kõigile vene põhikooli lõpetajatele eesti keele oskus tasemel, mis võimaldab jätkata õpinguid eesti keeles (vrd PGS 1997, §52 lg 1). Olukorra analüüsil ja järelduste tegemisel on aluseks valdkonda reguleerivad riiklikud arengukavad, õigusaktid, riiklik haridusstatistika ja valdkonnaga seonduvad uuringud.

\section{Riiklik programm "Integratsioon Eesti ühiskonnas 2000-2007"}

Eesti keele kui riigikeele õpe on selles Vabariigi Valitsuse poolt 14. märtsil 2000 heaks kiidetud dokumendis suure tähelepanu all. ${ }^{3}$ Riikliku programmi põhieesmärk on keelelis-kommunikatiivne integratsioon, st ühise teabevälja ja eestikeelse keskkonna taastootmine kultuurilise mitmekesisuse ja vastastikuse tolerantsuse tingimustes - programmi pearõhk on just selle protsessi soodustamisel (peatükk 1. Sissejuhatus). Selle vajadust nähakse asjaolus, et paljude mitteeestlaste eraldatus Eesti ühiskonnast on tingitud nende puudulikust eesti keele oskusest (peatükk 3.2). Programm näeb ette, et keskseks integratsioonivaldkonnaks kujuneb Eesti haridussüsteem, mille kaudu jõutakse olukorrani, kus muukeelse põhikooli lõpetanud noortel pole keelelisi ega kultuurilisi barjääre haridustee jätkamisel või tööturul konkureerimisel. Vene põhikooli lõpetanu on ühiskonnapädev ja valdab eesti keelt kesktasemel (peatükkt 1). Siit tulenevalt paraneb mitte-eestlaste eesti keele oskus märgatavalt ning eesti keel muutub valdavaks suhtlemise keeleks ühiskonnas (peatükk 3.2). Väga oluliseks peetakse, et seadusandlik taust, st Eesti Vabariigis vastu võetud õigus- ja normatiivaktid soodustaksid riikliku programmi põhieesmärkide saavutamist ja et sellealane arendustegevus toetaks alamprogrammide eesmärke ja tuleneks nende vajadustest ja tulemustest (peatükk 2). Programm deklareerib:

Eesti keele õppe tõhustamine võimaldab gümnaasiumiklassides üle minna eesti õppekeelele suures osas õppeainetes. Venekeelse õppe suundus ja maht fikseeritakse kooli õppekavas, arvestades õppekeelest erinevates keeltes läbiviidavaks õppeks seadusega sätestatud mahtu. (6.1.1.1)

Eesmärgi saavutamiseks seatakse ülesandeks "arendada välja ja võtta kasutusse erinevad keeleõppemallid, arvestades nende kokkusobivust.” (6.1.1.2.2) Sellega ühenduses on nimetatud kakskeelse õppega seotud tegevusi (nt üksikute ainete eesti keeles õpetamine, keelekümblusprogrammi väljatöötamine ja rakendamine), kuid ei osutata vajadusele muuta haridusseadustikku ja olemasolevat ükskeelset koolimudelit.

${ }^{3}$ Vt http://www.riik.ee/saks/ikomisjon/programm.htm (16.01.2006). 


\section{Eesti keele kui teise keele õppe riiklik korraldus}

Keeleõppekorraldus on üldise keelekorralduse osa, mille määravad riigi keelepoliitika ja sellest juhinduvad haridusalased õigusaktid, mis kajastavad riigikeele ja teiste keelte osatähtsust haridussüsteemis. Keeleõppekorralduse eesmärgiks ja ülesandeks on tagada järgmise põlvkonna sulandumine ühiskonda. Haridusprogrammide kavandamisel tuleb vahet teha ühelt poolt võõrkeelel, mida ei kasutata üldise suhtluskeelena, ja teiselt poolt kohalikul riigikeelel ehk muukeelsete laste jaoks teisel keelel, mis on vajalik selleks, et antud ühiskonnas toime tulla (Rannut jt 2003: $281 \mathrm{jj}$ ).

Riigi keelepoliitika aluspõhimõtted, sh haridust reguleerivad põhimõtted on esitatud Eesti põhiseaduses (PS, 1992) ja keeleseaduses (KS, 1995), kusjuures ülimuslik on põhiseadus. ${ }^{4}$

Põhiseadus (§ 37, $\lg 4)$ sätestab keelekasutuse hariduses järgmiselt:

Igaühel on õigus saada eestikeelset õpetust. Õppekeele vähemusrahvuse õppeasutuses valib õppeasutus.

Siit saab teha järelduse, et põhiseaduse järgi on Eestis üldjuhul õppekeeleks eesti keel, kuid vähemusrahvuse õppeasutuses on soovi korral õigus kasutada õppekeelena emakeelt. Selgituseks tuleb lisada, et vähemusrahvuse õppeasutuse all mõistetakse vähemusrahvuse kultuuriautonoomia seaduse (VKS) § $4 \lg 1$ ning erakooliseaduse (EKS) alusel asutatud õppeasutust. Õppekeele valik on erakooliseaduse alusel asutatud õppeasutuses vaba. Kuid lõpetajailt nõutav eesti keele oskuse tase on sisuliselt kindlaks määratud. EKS § $15 \lg 2$ sätestab:

Põhikoolis ja gümnaasiumis, kus eesti keel ei ole õppekeeleks, on eesti keele õpe kohustuslik riikliku õppekavaga määratud mahus, et lõpetaja võiks järgmisel haridustasemel jätkata õpinguid eesti keeles.

Täpsustavalt on oluline märkida, et vene õppekeelega riigi- või munitsipaalkoolid (nii üldhariduskoolid kui ka kutseõppeasutused) ei ole vähemusrahvuse õppeasutused, kuigi seda on teinekord tahetud nii tõlgendada.

Vähemusrahvuse keel on keeleseaduse määratluses (§ $2 \lg 2)$ :

.. võõrkeel, mida vähemusrahvusest Eesti kodanikud on Eestis põliselt kasutanud emakeelena.

Keeleseadus (§6) reguleerib hariduse keelsust järgmiselt:

Riigiasutused ja kohalikud omavalitsused tagavad seaduses ettenähtud korras eestikeelse hariduse omandamise võimaluse kõigis neile kuuluvates õppeasutustes, samuti võõrkeelse hariduse omandamise võimaluse seaduses ettenähtud korras.

Ülalesitatud paragrahvi esimene pool nõuab PS § 37-s deklareeritud õiguse "Igaühel on õigus saada eestikeelset haridust” praktilist tagamist.

Paragrahvi teine pool, mis puudutab võõrkeelset haridust, vajab lähemat selgitust. Riigiasutuse kohustus tagada võõrkeelse hariduse omandamise võimalus võib tähendada kaht eri asja:

\footnotetext{
${ }^{4}$ Nõu ja abi eest seaduste tõlgendamisel olen tänulik Keeleinspektsiooni peadirektorile IImar Tomuskile.
} 
1) seda, et riik (HTM) ei keeldu koolitusloa andmisest erakoolile, kui selle õppekeeleks on põhimääruses märgitud mis tahes keel peale eesti keele (see ei pruugi olla seotud vähemusrahvuse mõistega);

2) seda, et riik lubab asutada vähemusrahvuskeelse õppekeelega erakoole, järgides finantseerimisel seaduses ettenähtud nõudeid.

Kohaliku omavalitsuse kohustus tagada võõrkeelse hariduse omandamise võimalus peaks puudutama vaid munitsipaalkoole. Kuivõrd põhiseaduse järgi tuleks võõrkeelse hariduse all mõista vähemusrahvuse keeles antavat haridust (vt ülalpool PS § $37 \lg 4$ ), millega ei ole kohalik omavalitsus seotud, siis tuleks antud kohustust sisuliselt põhjendamatuks pidada.

\section{Haridusalased õigusaktid}

Peamised üldharidust reguleerivad õigusaktid, mis sätestavad ühtlasi ka eesti keele ja muude keelte staatusliku vahekorra ja õpetamise põhimõtted, on haridusseadus (vastu võetud 1992), põhikooli- ja gümnaasiumiseadus (vastu võetud 1993) ning riiklik õppekava. On oluline märkida, et mõlemad nimetatud seadused on vastu võetud perioodil, kui kehtis alles ENSV-aegne, 1989. a vastu võetud keeleseadus. Kuigi see oli tollases poliitilises kontekstis eesti keele õigusi maksimaalselt arvestav dokument, peegeldab see paratamatult ka keelepoliitilisi piiranguid, mis tulenesid Eesti sõltuvast staatusest.

Haridusseadus (HS) on vastu võetud 23. märtsil 1992, ajal, kus ei olnud veel vastu võetud Eesti põhiseadust ja kus ainukese dokumendina reguleeris keelepoliitikat 1989. a keeleseadus. Sellest lähtudes deklareerib HS, et

Eesti Vabariik tagab eesti keele õpetamise kõigis muukeelsetes avalikes õppeasutustes ja muukeelsetes rühmades. (§ $4 \lg 3$ )

Siin on korratud 1989. a keeleseaduse $\S 21$ sõnastust, mis eeldab muukeelset üldharidust, ja toetutud sama keeleseaduse §-le 19:

Eesti NSV tunnistab kõigi oma kodanike võrdset õigust riiklikule omakeelsele üldharidusele.

Venekeelne üldharidus tagatakse vastavalt venekeelse elanikkonna paiknemisele. $(\lg 3)$

Põhikooli- ja gümnaasiumiseadus (PGS) määrab kindlaks õppekeelte kasutamise üldhariduses ja eesti keele kui riigikeele õpetamise algusaja.

Õppekeele regulatsioon on seadusemuudatuste käigus järjest liberaalsemaks muutunud. PGS-i esialgses versioonis (1993) on eesti keel õppekeelena esile tõstetud, kuid samas on põhikoolis lubatud kasutada ka muid keeli:

Koolis on õppekeeleks eesti keel. Põhikooli õppekeeleks võib olla muu keel, kusjuures munitsipaalkooli puhul teeb vastava otsuse kohaliku omavalitsuse volikogu, riigikooli puhul Kultuuri- ja Haridusministeerium. (§ $9 \lg 1$ )

Ühtlasi sätestab § 52 lõige 2 ülemineku eestikeelsele gümnaasiumiõppele järgneva seitsme aasta jooksul: 
Käesoleva seaduse § 9 1. lõike jõustumiseks minnakse aastatel 1993-2000 riigi- ja munitsipaalgümnaasiumides üle eestikeelsele õppele.

1997. aastal lükatakse ülemineku tähtaeg edasi 2007. aastani (PGS 1997).

2000. a vastu võetud seadusemuudatus jätab eesti keelt puudutava üldsätte välja ja kehtestab ühemõtteliselt võimaluse omandada põhiharidus mis tahes keeles.

Põhikoolis, põhikooli üksikutes astmetes ja põhikooli üksikutes klassides võib õppekeeleks olla mis tahes keel - munitsipaalkoolides kohaliku omavalitsuse volikogu ja riigikoolides haridusministri otsuse alusel. Vastava ettepaneku kohaliku omavalitsuse volikogule teeb kooli hoolekogu. (PGS $2000 \S 9 \lg 1)$

Sama muudatusega täiendatakse $§ 9$ lõikega, mis määratleb, et

Gümnaasiumiastmes on õppekeeleks eesti keel. (PGS $2000 \S 9 \lg 1^{1}$ )

2002. a laiendatakse muude keelte kasutamise võimalust ka gümnaasiumiastmes:

(1) Gümnaasiumiastmes on õppekeeleks eesti keel. Munitsipaalkooli gümnaasiumiastmes ja munitsipaalkooli gümnaasiumiastme üksikutes klassides võib õppekeeleks olla ka mis tahes muu keel. Loa muus keeles toimuvaks õppetööks annab Vabariigi Valitsus kohaliku omavalitsuse volikogu taotluse alusel. Vastava ettepaneku kohaliku omavalitsuse volikogule teeb kooli arengukavast lähtudes gümnaasiumi hoolekogu.

See muudatus teeb ülemineku eesti õppekeelele gümnaasiumiastmes vabamaks, jättes võimaluse jätkata õpet ka võõrkeeles.

Eelnevast saab teha järelduse, et õppekeelte määratlus PGS-is ei vasta Eesti Vabariigi põhiseaduse vaimule ning lahkneb riigi keelepoliitilisest joonest. Võõrkeelte ja eesti keele staatuslik võrdsustamine hariduskeelena nõrgendab oluliselt eesti keele kui riigikeele seisundit, võttes riigilt ära võimaluse liita ühiskonda keeleliselt ja takistades muukeelsete elanike sulandumist ühiskonda.

2005. a detsembrikuus esitas HTM kooskõlastamiseks PGS-i muutmise seaduseelnõu, et muuta järjekordselt paragrahvide 9 ja 52 sisu (Eelnõu 2005). Eelnõu järgi § 9 lõige $1^{2}$ muudetakse ${ }^{5}$ ja sõnastatakse järgmiselt:

(1 $\left.{ }^{1}\right)$ Gümnaasiumiastmel õpetatakse eesti kirjandust, ühiskonnaõpetust, ajalugu (eesti ajaloo kursuse osas), geograafiat, muusikaõpetust ning kooli valikul veel vähemalt kahte õppeainet eesti keeles.

Paragrahvi 52 täiendatakse lõikega 4 järgmises sõnastuses:

(4) Eesti keelest erineva õppekeelega koolide gümnaasiumiastmel alustatakse käesoleva seaduse $\S 9$ lõikes $1^{2}$ nimetatud õppeainetes eestikeelset õpet vastavalt riiklikult ettevalmistatud üleminekule ning põhikooli- ja gümnaasiumi riiklikus õppekavas sätestatud ajakava kohaselt. Ajakava sätestatakse arvestusega, et alates 2007/2008. õppeaastast alustatakse igal järgneval õppeaastal eestikeelset oppet vähemalt ühes nimetatud õppeaines.

Vaadeldav eelnõu on sisulises vastuolus seadusega.

${ }^{5} \S 9$ lõike 12 praegune sõnastus: "Kooli või klassi õppekeeleks loetakse keel, milles toimuv õpe moodustab 
PGS-i § 52 lõige 1 nõuab, et muukeelse kooli õppekava ja koolikorraldus peavad aastaks 2007 kõigile põhikooli lõpetajatele tagama eesti keele oskuse tasemel, mis võimaldab jätkata õpinguid eesti keeles. See tähendab, et 2007. a sügisel peaksid kõik kümnendad klassid alustama õpet eesti keeles. See on eesti õppekeelele ülemineku algus, sest ülejäänud gümnaasiumiklassid (11. ja 12. klass) jätkavad õpinguid endise õppekava järgi. Eelnõus aga tõlgitsetakse ülemineku alustamist eesti õppekeelele meelevaldselt - ühe aine kaupa seitsme aasta jooksul (Eelnõu 2005b).

PGS-i § 52 lõige 1 peab eestikeelsele õppele ülemineku vältimatuks eelduseks ettevalmistustöid põhikoolis. Eelnõu jätab põhikooli sellest protsessist täiesti kõrvale, pidades võimalikuks alustada üleminekut tühjalt kohalt. See on vastuolus ka riikliku integratsiooniprogrammi ja eesti keele arendamise strateegia seisukohtadega.

1) Eelnõus on ette määratud ained, mida tuleks gümnaasiumis eesti keeles õpetada. Seadus aga sätestab ülemineku eesti õppekeelele.

2) Eelnõu seletuskirjas väidetakse, et "Vastavalt kehtivale seadusandlusele peab algama vene õppekeelega koolide gümnaasiumiastmel eesti keeles õpetamine senisest suuremas ulatuses.” (Eelnõu 2005a) Tegelikult nõuab seadus ühemõtteliselt üleminekut eesti õppekeelele (PGS § $52 \lg 2$ ).

Sisuliselt kujutab kõnealune eelnõu endast ummikteed, mis ei võimalda saavutada soovitud tulemust, sest alustatud on valest otsast.

Eesti keele õpetamine muukeelses koolis või klassis oli kuni 1999/200o. õppeaastani kohustuslik alates 3. klassist ( $\$ 9 \lg 2)$. 1999. aastast peale on eesti keele õpetamine kohustuslik ka muukeelses lasteaias (KLS 1999 § 8 lg 4) ja 1. septembrist 2000 nõuab põhikooli- ja gümnaasiumiseadus eesti keele õppe alustamist 1. klassist (PGS $1999 \S 9 \lg 2$ ).

Kuigi seadus otseselt ei ütle, millisel viisil tuleb eesti keelt muukeelses koolis õpetada, määratleb selle ära kontekst. Kui õppetöö toimub muus keeles, siis eesti keelt saab ja tuleb õpetada tavapärasel võõrkeelemeetodil, tunniõppe vormis. Kohustusliku eesti keele õppe varasem algus on üks võimalus mõjutada õppe tulemuslikkust olemasoleva süsteemi raames. Kuid oluline on märkida, et varasem algus ei toonud kaasa õppemahu suurenemist (vrd tabel 3). Pigem vastupidi: eesti keele õppeks ettenähtud tundide arv on isegi mõnevõrra väiksem kui see oli 1995/1996. õppeaastal.

2002. a-st kehtib ka PGS-i nõue, et kooli arengukavas määratakse "eesti õppekeelele üleminekuks vajalikud ja võimalikud meetmed muukeelses gümnaasiumis.” (PGS 2002) Esimesel pilgul näib see säte olevat seotud ettevalmistusega üleminekuks eesti õppekeelega gümnaasiumile. Sisuliselt see nii siiski ei ole, sest säte ei puuduta muudatusi põhikoolis, nagu nõuab seaduse § 52, vaid reguleerib iga konkreetse kooli õppekava ${ }^{6}$ gümnaasiumiastmes. 


\section{Riiklik õppekava}

Lähtudes põhikooli- ja gümnaasiumiseadusest, täpsustab riiklik õppekava eesti keele õpetamise viisi ja mahu muukeelses koolis ning põhikooli lõpuks nõutava oskustaseme. Õppekava järgi tuleb eesti keelt õpetada vene või muu õppekeelega koolis A-võõrkeelena (RÕK $2002 \S 11 \lg 5$ ). See määrab otseselt ära eesti keele staatuse vene koolis: eesti keel kui riigikeel on sisuliselt võrdsustatud Eestis õpetatavate võõrkeeltega, nagu inglise, saksa või prantsuse keel. Siit järeldub ühtlasi, et vene laste ópetamisel kasutatakse Eestis segregatiivse iseloomuga haridusprogrammi (vrd Rannut jt 2003: 287). Seda võimaldab põhikooli- ja gümnaasiumiseadus, mis lubab kohustusliku põhihariduse korral kasutada vabalt mis tahes õppekeelt, jättes eesti keelele muukeelses koolis pelgalt võõrkeele rolli. Mõningaid eeliseid muude võõrkeeltega võrreldes eesti keelel siiski on: 1) eesti keel ei ole vene koolis vabalt valitav, vaid on kõigile koolidele kohustuslik A-võõrkeel; 2) eesti keele õpe algab varem (1. klassist) kui muude A-võõrkeelte puhul (3. klassist ${ }^{7}$ ) ja 3) eesti keele õppeks ettenähtud tundide arv on mõnevõrra suurem (vt tabel 4).

\section{Eesti keele õppe maht}

Keeleõppeks ettenähtud aeg, tundide arv on üks olulisi õppe tulemuslikkust mõjutavaid tegureid, kuid arvestada tuleb asjaoluga, et eesti keele õppe mahu vene põhikoolis määrab riiklik koolimudeli tüüp.

1997/1998. õppeaastast alates ei määratleta ainetundide arvu erinevalt varasemast enam klasside kaupa, vaid kohustuslik nädalatundide arv on antud kooliastmete järgi (tabel 3). Õpetajal on õigus tunde klasside vahel paindlikult, sobival viisil jagada.

Tabel 3. Eesti keele tundide arv klasside kaupa aastate ulatuses

\begin{tabular}{|c|c|c|c|c|c|c|c|c|c|c|c|c|}
\hline \multirow{2}{*}{ Õppeaasta } & \multicolumn{12}{|c|}{ Klass } \\
\hline & 1 & ॥ & III & IV & $\mathrm{V}$ & $\mathrm{VI}$ & VII & VIII & IX & $x$ & $\mathrm{XI}$ & XII \\
\hline $1990 / 91$ & - & - & 4 & 4 & 3 & 3 & 2 & 2 & 2 & 2 & 2 & 2 \\
\hline $1991 / 92$ & - & - & 4 & 4 & 3 & 3 & 2 & 2 & 2 & 2 & 2 & 2 \\
\hline $1993 / 94$ & - & - & 4 & 4 & 3 & 3 & 3 & 3 & 3 & 3 & 3 & 3 \\
\hline $1994 / 95$ & - & - & 4 & 4 & 3 & 3 & 3 & 3 & 3 & 3 & 3 & 3 \\
\hline $1995 / 96$ & - & -13 & 5 & 5 & 4 & 3 & 3 & 3 & 3 & 3 & 3 & 3 \\
\hline $1996 / 97$ & - & -13 & 5 & 5 & 4 & 3 & 3 & 3 & 3 & 3 & 3 & 3 \\
\hline Astmete kaupa & \multicolumn{3}{|c|}{ I-III kokku } & \multicolumn{3}{|c|}{ IV-VI kokku } & \multicolumn{3}{|c|}{ VII-IX kokku } & \multicolumn{3}{|c|}{ X-XII kokku } \\
\hline 1997/98-2001 & \multicolumn{3}{|c|}{$\min 6-\max 10$} & \multicolumn{3}{|c|}{$\min 12-\max 15$} & \multicolumn{3}{|c|}{$\min 12-\max 15$} & \multicolumn{3}{|c|}{9} \\
\hline $2001 / 02-$ & \multicolumn{3}{|c|}{6} & \multicolumn{3}{|c|}{12} & \multicolumn{3}{|c|}{12} & \multicolumn{3}{|c|}{9} \\
\hline
\end{tabular}

${ }^{7}$ Ajaline erinevus kehtib alates 1.09.2000. a. Enne seda algas kohustuslik eesti keele õpe samuti 3. klassist 
Arvestades asjaolu, et venekeelne elanikkond on koondunud suurte eraldiseisvate kogukondadena valdavalt Tallinnasse ja selle ümbruskonda ning Ida-Virumaale, on eesti keele õppe maht liiga väike selleks, et vähegi rahuldavat tulemust anda. Eriti annab see tunda kolmes esimeses klassis, kus eesti keele õppeks on ette nähtud keskmiselt vaid kaks nädalatundi.

Eesti keele õppe mahu suurendamiseks praeguse koolimudeli raames puudub aga võimalus, sest see tähendaks paratamatult mõne teise aine mahu või valikainetundide vähendamist. Valikainetunde, mille kasutamise üle otsustab kool, ongi vene koolis vähem ette nähtud kui eesti koolis (vrd RÕK 2002 § 14, lg 2; $\S 17, \lg 2 ; \S 20, \lg 2)$, sest selle arvel on suurendatud eesti keele kui A-võoorkeele tundide arvu (tabel 4).

Tabel 4. Eesti keele ja muude A-võõrkeelte ning valikainetundide arv põhikoolis riikliku õppekava järgi

\begin{tabular}{|l|c|c|c|c|}
\hline \multirow{2}{*}{ Kooliaste } & \multicolumn{2}{|c|}{ A-võórkeel } & \multicolumn{2}{c|}{ Valikainetunnid } \\
\cline { 2 - 5 } & $\begin{array}{c}\text { Eesti keel vene } \\
\text { koolis }\end{array}$ & Muud keeled & Vene kool & Eesti kool \\
\hline 1.-3. klass & 6 & 3 & 4 & 7 \\
\hline 4.-6. klass & 12 & 9 & 7 & 10 \\
\hline 7.-9. klass & 12 & 9 & 4 & 7 \\
\hline
\end{tabular}

\section{Vene põhikooli lõpetajailt nõutav eesti keele oskuse tase}

1997. a sätestatud PGS-i § 52 lg 1 kohustab, et muukeelse põhikooli õppekava ja koolikorraldus peavad aastaks 2007 tagama kõigile põhikooli lõpetajatele eesti keele oskuse tasemel, mis võimaldab neil jätkata õpinguid eesti keeles ${ }^{8}$. Euroopa Nõukogu keeleoskussüsteemi skaalal vastab eeldatav oskus vähemalt kesktaseme kõrgemale astmele (B2)9 (vrd EKR 2003: 20-24, Hausenberg jt 2003: 15 jj). Samasuguse keeleoskustaseme seab eesmärgiks ka "Eesti keele arendamise strateegia 2004-2010":

.. saavutada, et muu õppekeelega põhikooli õpilased omandavad eesti keele tasemel B2, mis loob võimalused asuda õppima 2007. aastal eesti õppekeelele üleminekut alustavas gümnaasiumis ja tulla toime Eesti ühiskonnas. (EKAS: 27)

Sellist oskustaset ei ole aga võimalik saavutada emakeelse aineõppe tingimustes, vaid see eeldab kakskeelset aineõpet põhikoolis (vrd Rannut jt 2003: 287), millele juhtis tähelepanu ka keelestrateegia Euroopa Nõukogu ekspert professor Pa' draig O'Riaga' in Tallinnas peetud teisel keelefoorumil 5. detsembril 2003. Samal seisukohal on 2004. a sügisel läbi viidud Emori küsitluses osalenud vene koolide õpetajad, kes üldjuhul toetasid eestikeelse aineõppe sisseviimist alates algklassidest ning selle mahu järkjärgulist suurendamist põhikooliastmes, mis annaks vajaliku ettevalmistuse eestikeelse aineõppega jätkamiseks gümnaasiumiastmes (Emor 2004: 91). Ka õpilaste arvates tuleks eestikeelse aineõppega alustada juba

${ }^{8}$ Hilisema seadusemuudatusega asendati sõnad "eestikeelsele õppele" sõnadega "eesti õppekeelele" (PGS 2000).

${ }^{9}$ B2 on edasijõudnud keelekasutaja tase (vrd EKR: 20 jj). 
varasemates klassides või koguni lasteaias, mitte alles gümnaasiumiosas, kus õpilastel puudub vastav ettevalmistus ja kohene valmisolek eesti keeles ainete õppimiseks. Üleminek peaks olema loomulik ja järkjärguline protsess (samas: 104).

Vaatleme järgnevalt, kas ja kuivõrd on seda taset arvestatud riiklikus õppekavas.

Need lapsed, kes lõpetavad põhikooli 2007. a ja peaksid olema suutelised jätkama õpinguid eesti keeles, astusid kooli 1998. a. Samal aastal hakkas kehtima ka uus õppekava (RÕK $1996^{10}$ ), mis aga ei arvesta seaduses sätestatud ülesandeid. Õppekava ei sea eesmärgiks vene põhikooli lõpuks niisugust eesti keele oskuse taset, mis võimaldab jätkata õppimist eesti keeles, vaid taotleb, et õpilane omandab eesti keele tasemel, "mis rahuldab olulisemad igapäevaelu suhtlemisvajadused nii kõnes kui kirjas.” (EKA 1997: 1.1, üldkirjeldus 2.2.1.1) Euroopa Nõukogu keeleoskustasemete üldskaala mõistes vastab see suhtluslävele (ingl threshold level, vrd Ehala jt 1997). Üldskaalal tähistab seda kesktaseme madalam aste B1, mis eeldab nii suulises kui ka kirjalikus keelekasutuses eeskätt igapäevases suhtluses ja iseendaga seotud teemade valdamist (EKR 2003: $20 \mathrm{jj}$; Hausenberg jt 2003: $15 \mathrm{jj})$.

Alates 2002/2003. õppeaastast on kasutusel uus õppekava (RÕK 2002), mis jätab põhikooli lõpetaja eesti keele oskuse taseme määratlemata (vrd lisa 7: 5•3, 5.4). Järeldusi nõutava taseme kohta saab teha põhikooli lõpueksami järgi. Tartu Ülikooli eksperthinnang eesti keele kui teise keele põhikooli lõpueksamile aastatel 2002-2004 näitab, et põhikooli lõpueksamiga kontrollitav oskustase kõigub vahemikus A1 kuni B1:

.. ülesannete raskusaste on eksamitöödes kõikuv: osa ülesandeid näib vastavat A2 tasemele (mõni küsimus on isegi vaid A1 tasemel) ${ }^{11}$, osa aga B1 tasemele.

Kokkuvõttes tulevad eksperdid järeldusele, et kui lähtuda sellest, et õpilaste keeleoskus põhikooli lõpuks peaks olema B1 tasemel, siis on eksam praegusel kujul liiga lihtne (Kikerpill, Türk 2005: 29). Eelneva põhjal saab väita, et vene põhikooli lõpetajatelt nõutav eesti keele oskus ei vasta tasemele, mis võimaldaks õppida eesti keeles. Riiklik õppekava ei taga üleminekut eesti õppekeelega gümnaasiumile 2007. a.

Selle peatüki kokkuvõtteks võib öelda, et riiklikku keeleõppekorraldust iseloomustab kolm põhimõttelise tähtsusega joont.

1) Haridusprogrammide kavandamisel ei ole sisulist vahet tehtud võõrkeeleõppel ja eesti keele kui teise keele (K2) õppel: eesti keelt õpetatakse vene koolis traditsioonilisel võõrkeeleõppe meetodil.

2) Eesti keelel puudub kohustusliku üldhariduse õppekeelena vähimgi eelis võõrkeeltega võrreldes.

3) Vene laste õpetamisel kasutatakse segregatiivse iseloomuga haridusprogrammi, kus kogu aineõpe, keeleõpe välja arvatud, toimub lapse emakeeles, esimeses keeles (K1).

Oma iseloomult kuulub see nõrkade kakskeelsete haridusprogrammide hulka, mille eesmärgiks ja tulemuseks on ükskeelsus K1-s ja piiratud oskus K2-s

10 Õppekava oli küll juba varem, 1996. a vastu võetud, kuid rakendama hakati seda etappide kaupa alates

${ }^{11}$ A1 ja A2 tähistavad algelist keelekasutust (lähemalt EKR 2003: 22 jj, Hausenberg jt 2003). 
(vrd Rannut jt 2003: 286-287). Sellisel viisil on võimalik küll omandada teatud tasemel passiivne keeleoskus, mitte aga aktiivset keeleoskust, mis on hädavajalik selleks, et õpitava keele keskkonnas edukalt toime tulla (Vare 1999: 45-56).

Ka Eestis läbi viidud sotsioloogiliste ja pedagoogiliste küsitluste ning uuringute andmeil võib väita, et ükskeelne koolimudel ei taga teise keele omandamist, ei võimalda saavutada keeleoskust, mis on vajalik selleks, et Eesti ühiskonnas hakkama saada. Siia kuuluvad näiteks 2000. a rahvaloenduse andmed ${ }^{12}$, mis väljendavad üldist keeleoskust inimeste endi hinnangu järgi skaalal oskan-ei oska. Küsitlusest selgub, et 15-19-aastastest noortest, kelle kogu gümnaasiumiaeg ja ka valdav osa põhikoolist langeb ajavahemikku 1991-2000, oskab enda väitel eesti keelt 59,28\%. Siit järeldub, et 40,72\% üldhariduskooli lõpetanutest ei oska omaenda hinnangul eesti keelt. Noorte muulaste nappi eesti keele oskust näitab samuti Phare eesti keele programmi tellimusel läbiviidud kompleksuuring, millest selgub, et 15-24-aastaste vanuserühmas ei oska eesti keelt 23\% ja 14\%-l on üksnes passiivne keeleoskus (Phare 2002: 44). Siit järeldub, et $37 \%$ vene põhikooli ja gümnaasiumi lõpetanud noortest ei suuda eesti keeles algeliselgi tasemel suhelda, rääkimata toimetulekust töös või õpinguis.

Sotsioloogiliste küsitluste andmeid kinnitavad pedagoogiliste uurimuste tulemused. Tartu Ülikoolis on uuritud vene põhikooli kesk-ja vanema astme õpilaste eesti keele sõnavara ja kommunikatiivsete võimete arengut. Tulemused näitavad, et riikliku tavaprogrammi õpilaste suhtlusvõime on äärmiselt madal, küündimata isegi selle alampiirini (Asser 2001, Vare 2004: 41 jj). Ühtlasi selgub võrdlusest kontrollrühmaga, et tavaprogrammi õpilaste eesti keele oskus jääb oluliselt maha kakskeelses programmis osalenud õpilaste oskusest. Tallinna Ülikooli (varasema Pedagoogikaülikooli) kogemusel on ka paljude vene gümnaasiumi lõpetajate eesti keele oskus väga piiratud, seda nii suulise kui ka kirjaliku väljenduse osas (Volkova 2001, Vare 2004: 23 jj).

Ka "Eesti keele arendamise strateegias 2004-2010" nenditakse, et

Paljude muukeelse üldhariduskooli lõpetajate eesti keele oskus on selleks ebapiisav, et eesti keelekeskkonnas edasi õppida ja/või tööle asuda. (EKAS 2004: 27)

Kehva keeleoskuse põhjustena tuuakse esile kaks peamist asjaolu: eesti keele riigieksami madalad nõuded ja ükskeelne koolimudel, kus aineõpe on põhiosas venekeelne, eesti keele õpe piirdub üldjuhul vaid eesti keele tunniga ja kus keele omandamist toetav eestikeelne keskkond koolis puudub.

\section{Alternatiivsed keeleõppeprogrammid}

Kuigi riiklikus plaanis on vene laste koolitamisel endiselt kasutusel ükskeelne haridusprogramm, ei toimi see paljudel juhtudel enam oma puhtal kujul. Enamikus koolides kasutatakse selle kõrval või asemel mitmesuguseid kakskeelse õppe vorme, kus suuremal või vähemal määral toimub eestikeelset aineõpet. Eristada võib süsteemseid ja koordineerimata ehk juhuslikumat laadi arenguid. Järgneva käsitluse eesmärgiks on vaadelda neid vorme lähemalt ja hinnata, kas ja kuivõrd

12 http://www.stat.ee/ (15.02.2004). 
võimaldab eestikeelne aineõpe oma praegusel kujul ja praeguses ulatuses alustada üleminekut eesti õppekeelega gümnaasiumile 2007. a.

\section{Eestikeelse aineõppe ulatus}

SA Innove Hariduse ja Tööhõive Seirekeskuse haridusstatistika põhjal (Ained 2005) on võimalik teha täpsemaid järeldusi eestikeelse aineõppe ulatuse ja iseloomu kohta vene põhikoolis. Alltoodud andmed peegeldavad olukorda 2004/ 2005. ôppeaastal.

Eestikeelne aineõpe puudub 37 koolis, kus kogu põhikooli ulatuses ühtki ainet üheski klassis eesti keeles ei õpetata. ${ }^{13}$ Kokku õpib neis koolides 8456 õpilast ehk üle veerandi (26,01\%) kõigist vene põhikooli õpilastest. Valdav osa sellistest koolidest asub Ida-Virumaal (18) ja Tallinnas (7).

Eestikeelses aineõppes ${ }^{14}$ (arvestades selle erinevaid vorme) osaleb kokku 10169 õpilast, mis on $31,28 \%$ vene põhikooli õpilaste üldarvust.

Enamasti on eestikeelse aineõppega seotud vaid osa sama kooli õpilastest, kusjuures ülejäänud jätkavad õppimist riikliku tavaprogrammi järgi. Seetõttu ei saa koolide arvu põhjal teha järeldusi eestikeelse aineõppe kasutusulatuse kohta. Kuigi eestikeelset aineõpet kasutatakse sel või teisel määral paljudes koolides, on ükskeelne õppeprogramm, kus eesti keele õpe piirdub vaid eesti keele tunniga, ikka veel konkurentsitult esikohal. Nii õpib ligi 69\% vene põhikooli õpilastest riikliku tavaprogrammi järgi, 27\% osaleb piiratud eestikeelses aineõppes ja 4,2\% keelekümblusprogrammis. Ülevaate erinevates keeleõppevormides osalevate õpilaste arvulise jagunemise kohta annab joonis 3. Eestikeelse aineõppe ulatus erineb piirkonniti olulisel määral (vrd tabel 5).

Tabel 5. Eestikeelse aineõppe kasutamine piirkonniti 2004/2005. õppeaastal

\begin{tabular}{|l|r|r|r|}
\hline \multirow{2}{*}{ Piirkond } & \multirow{2}{*}{ Öpilasi kokku } & \multicolumn{2}{c|}{ Eestikeelne aineõpe } \\
\cline { 3 - 4 } & & Õpilaste arv & Osalusprotsent \\
\hline Eesti tervikuna & 32510 & 10169 & 31,28 \\
\hline Tallinn & 14007 & 4998 & 35,68 \\
\hline Harjumaa & 2277 & 446 & 19,58 \\
\hline Ida-Virumaa & 12032 & 2242 & 18,63 \\
\hline Jõgevamaa & 208 & 187 & 89,9 \\
\hline Järvamaa & 46 & 0 & 0 \\
\hline Läänemaa & 158 & 49 & 31,01 \\
\hline L-Virumaa & 623 & 392 & 62,92 \\
\hline Pölvamaa & 55 & 55 & 100 \\
\hline Pärnumaa & 773 & 223 & 28,85 \\
\hline Tartumaa & 1630 & 1288 & 79,02 \\
\hline Valgamaa & 569 & 187 & 32,86 \\
\hline Viljandi & 49 & 19 & 38,77 \\
\hline Võru & 83 & 83 & 100 \\
\hline
\end{tabular}

${ }^{13}$ Nende hulka on arvatud ka koolid, kes on märkinud ainukeseks eesti keeles õpetatavaks aineks eesti keele

${ }^{14}$ Eestikeelse aineõppe all on antud artiklis mõistetud ainete (v.a keeleained) õpetamist eesti keeles. 


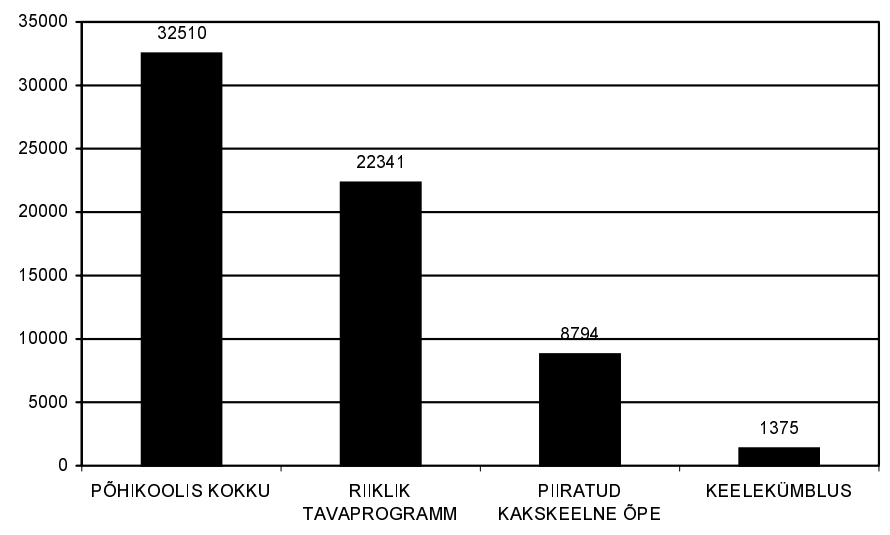

Joonis 3. Vene põhikooliõpilaste jagunemine eri keeleõppevormide vahel

\section{7. klass}

7. klassi õpilastest, kes lõpetavad põhikooli 2007. a ja keda koolireform esimesena otseselt puudutab, osaleb eestikeelses aineõppes kokku 1085 õpilast, mis on veidi üle veerandi $(26,42 \%) 7$. klassi õpilaste üldarvust (4107). Üldse on kokku 25 kooli, kus kõik 7. klassi õpilased õpivad vähemalt üht ainet eesti keeles. Ülejäänud juhtudel osaleb eestikeelses aineõppes vaid osa sama kooli 7. klassi õpilastest. Eesti keele kasutamise ulatus 7. klassi õppekeelena varieerub ühest ainest kuni täieliku eestikeelse õppeni: ainult ühte ainet õpetatakse eesti keeles 16 koolis, kaht ainet 5 koolis, kolme ainet 9 koolis ja nelja või rohkemat ainet 6 koolis. Paikkonniti on olukord erinev, ulatudes täielikust eestikeelsest aineõppest kuni selle täieliku puudumiseni.

\section{Keelekümblus}

Et parandada eesti keele õppe tulemuslikkust vene üldhariduskoolis, võeti 2000. a alternatiivse võimalusena senise võõrkeeleõppemeetodi kõrvale kasutusele uus, kakskeelsusele orienteeritud õppevorm - keelekümblus. See on riigi osalusel toimiv kakskeelse õppe süsteemne programm, mis on riikliku programmi "Integratsioon Eesti ühiskonnas 2000-2007" alamprogrammi "Haridus" osa. Riikliku integratsiooniprogrammi peamiseks sisuks on

.. toetada indiviidide integreerumist Eesti ühiskonna tugeva ühisosa ümber. Eesti ühiskonna tugev ühisosa on territoriaalselt määratletud Eestiga ning tugineb ühisele keelele - eesti keelele, mis on avaliku sfääri institutsioonide toimimise aluseks.

Programm deklareerib, et 
Muukeelse põhikooli lõpetanu on ühiskonnapädev ja valdab eesti keelt kesktasemel, ta saab õpinguid jätkata kutseõppeasutuses või gümnaasiumis, kus valdav osa õppest toimub eesti keeles. (ptk 6.1)

Üks olulisi eesmärke selle saavutamiseks on arendada vene õppekeelega koolis välja ja võtta kasutusse erinevad keeleõppemallid (6.1.1.2.2). Muude kõrval kuulub sinna hulka keelekümblusprogrammi väljatöötamine ja rakendamine, samuti üksikute ainete õpetamine eesti keeles.

Eesti keelekümblusprogrammi väljatöötamisel on toetutud Kanada ja Soome hariduskorralduse kogemusele. Uue metoodika arendamist, rakendamist ja levikut juhib Integratsiooni Sihtasutuse juures tegutsev Keelekümbluskeskus. ${ }^{15}$ Keskuse eesmärgiks on jõuda olukorrani, kus keelekümblus oleks Eesti haridussüsteemi lahutamatu osa.

Tavapärase võõrkeeleõppemeetodiga võrreldes avardab uus metoodika keeleõppija võimalusi olulisel määral: programmi eesmärgiks on anda õpilasele võrdselt head oskused nii emakeeles kui ka teises keeles. Keelekümbluse olulisi tunnuseid on, et vähemalt pool õppemahust omandatakse teises keeles. See loob koolis õpitava keele keskkonna, annab võimaluse ja vajaduse seda keelt kasutada ja kasutamise kaudu omandada. Kümblusprogrammis õpetatakse teises keeles kõiki aineid, k.a matemaatika ja loodusained, mis tagab õpilaste sõnavara mitmekülgse arengu. On oluline rõhutada, et programm ei kahjusta teadmisi, vaid näeb ette samaväärsete teadmiste omandamist, mida nõutakse tavaprogrammi korral. Meetod ei kahjusta ka emakeele arengut.

Uus õppemeetod on lühikese ajaga suurt huvi äratanud ja poolehoidu võitnud ning jõudsalt laienenud. Programmi algusaastal õppis selle raames nelja kooli viis klassi, kokku 134 õpilast. 2005/2006. õppeaastal on keelekümblusega liitunud kokku ligi 50 haridusasutust. Programmi rakendatakse 17 lasteaias ja 32 koolis ning selles osaleb kokku üle 2500 õppija (vt joonis 4 ja tabel 7). Keelekümblus-

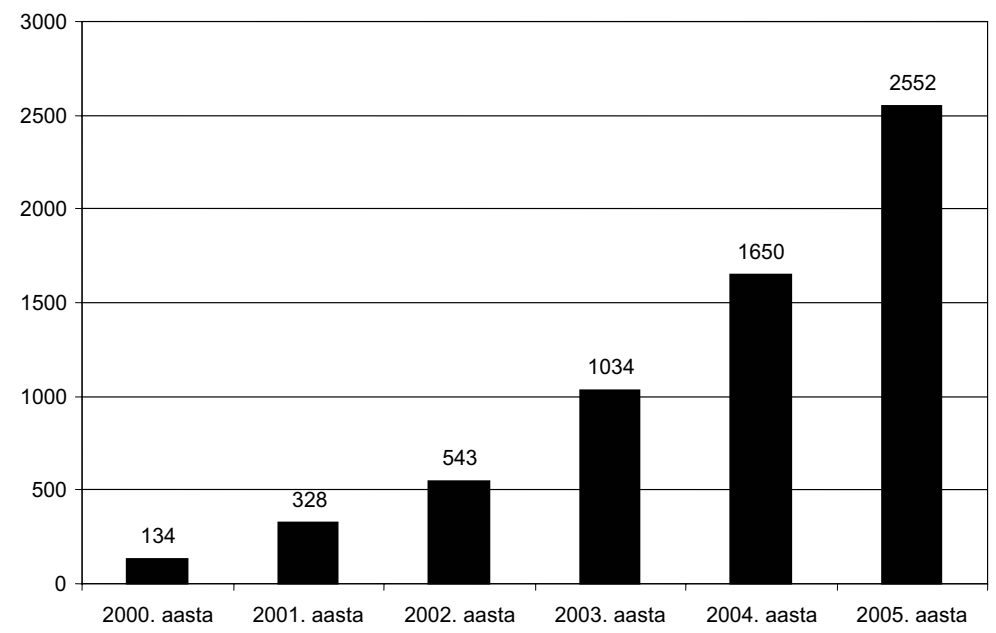

Joonis 4. Keelekümblusprogrammis õppijate arv aastate lõikes

\footnotetext{
${ }^{15}$ www.kke.ee (15.02.2004).

${ }^{16}$ Eestis liitusid esimesed lasteaiad keelekümblusega programmi 3. aastal.
} 
keskuse andmeil on nende hulgas 479 lasteaialast ja 2073 üldhariduskooliõpilast, mis moodustab 7,34\% vene põhikooliõpilaste üldarvust 2005/2006. õppeaastal.

Praegu on Eestis kasutusel kaks erinevat kümblusprogrammi vormi: varane täielik ja hiline täielik keelekümblus, mis erinevad teineteisest algusaja ning eesti- ja venekeelse õppe mahu poolest. Programmiga liitunud koolidest moodustavad suure osa need, kus oli eestikeelset aineõpet juba varemgi kasutatud.

Varane täielik keelekümblusprogramm haarab 1.-6. klassi õpilasi, millele eelneb eesti keele õpe lasteaias ${ }^{16}$ (vt tabel 6). Esimesel kooliaastal toimub kogu õpe eesti keeles. Teises klassis lisanduvad emakeele (vene keele) tunnid ja seejärel tulevad järk-järgult sisse venekeelne aineõpe ning võoorkeeleõpe. Programmi lõpuks (6. klass) eesti ja vene keele vahekord võrdsustub, pool aineõppest toimub eesti ja pool vene keeles. Programmi lõppedes jätkub kakskeelne õpe põhikooli lõpuni.

Tabel 6. Erinevate keelte osakaal protsentides varase täieliku keelekümbluse korral

\begin{tabular}{|l|r|r|c|}
\hline \multirow{2}{*}{ Piirkond } & \multirow{2}{*}{ Oppilasi kokku } & \multicolumn{2}{c|}{ Eestikeelne aineõpe } \\
\cline { 3 - 4 } & & Õpilaste arv & Osalusprotsent \\
\hline Eesti tervikuna & 32510 & 10169 & 31,28 \\
\hline Tallinn & 14007 & 4998 & 35,68 \\
\hline Harjumaa & 2277 & 446 & 19,58 \\
\hline Ida-Virumaa & 12032 & 2242 & 18,63 \\
\hline Jõgevamaa & 208 & 187 & 89,9 \\
\hline Järvamaa & 46 & 0 & 0 \\
\hline Läänemaa & 158 & 49 & 31,01 \\
\hline L-Virumaa & 623 & 392 & 62,92 \\
\hline Põlvamaa & 55 & 55 & 100 \\
\hline Pärnumaa & 773 & 223 & 28,85 \\
\hline Tartumaa & 1630 & 1288 & 79,02 \\
\hline Valgamaa & 569 & 187 & 32,86 \\
\hline Viljandi & 49 & 19 & 38,77 \\
\hline Võru & 83 & 83 & 100 \\
\hline
\end{tabular}

Esimesed varase täieliku kümblusprogrammiga klassid alustasid tööd 200o/ 2001. oppeaastal. Esimesed lasteaiad liitusid programmiga 2002/2003. õppeaastal. 2005. a sügisest osaleb varases täielikus kümblusprogrammis juba 17 lasteaeda ja 12 kooli (tabel 7). ${ }^{17}$

Hiline täielik keelekümblusprogramm on suunatud põhikooli lõpuastmele, 7.-9. klassile. Sellele eelneb ettevalmistav aasta 6. klassis, kus suureneb eesti keele ja eesti keeles õpitavate ainete maht: iga päev on kaks eestikeelset tundi. 7. ja 8. klassis õpitakse kõiki aineid eesti keeles (kokku 76\% õppekavast), välja arvatud emakeele (vene keel) ja võõrkeele õpe. 9. klassis on eestikeelse õppe maht 60\%. Esimesed 4 kooli liitusid programmiga 2003/2004. õppeaastal, 2005/ 2006. õppeaasta seisuga töötab programm juba 20 koolis ja kava kohaselt liitub 2006. a sügisel hilise keelekümbluse programmiga veel 2 kooli.

17 Vt http://www.kke.ee/index.php?lang=est\&menus_ID=6\&pages_ID=6\&mark=0 (12.01.2006). 
Tabel 7. Keelekümblusprogrammide levik õppeaastate lõikes ajavahemikus 2000-2005

\begin{tabular}{|c|c|c|c|c|c|c|}
\hline \multirow{2}{*}{ Programmi tüüp } & \multicolumn{5}{|c|}{ Osalevate haridusasutuste arv } \\
\cline { 2 - 7 } & $2000 / 01$ & $2001 / 02$ & $2002 / 03$ & $2003 / 04$ & $2004 / 05$ & $2005 / 06$ \\
\hline varane kk & & & & & & \\
\hline lasteaiad & - & - & 9 & 9 & 9 & 17 \\
\hline koolid & 4 & 7 & 7 & 7 & 7 & 12 \\
\hline hiline kk & - & - & - & 4 & 12 & 20 \\
\hline
\end{tabular}

\section{Keelekümblusprogrammi tulemuste uuring}

Programmi juurde kuulub tulemuste järjepidev seire, et programmi pädevalt suunata ja korrigeerida. Nii on see toimunud ka Eestis: koos kümblusprogrammi käivitamisega 2000/2001. õppeaastal alustati ka uurimistööga. Uuringu tulemused näitavad, et juba esimese õppeaasta jooksul paraneb keelekümblusõpilaste eesti keele oskus märkimisväärselt. Kuigi see jääb eesti kooli õpilastest veel palju maha, jõuavad kümblusprogrammi õpilased juba 1. klassi lõpuks venekeelsest kontrollgrupist kaugele ette nii lugemis-, kirjutamis-, kuulamis- kui ka rääkimisoskuse ning samuti grammatilise korrektsuse poolest. Kui õppeaasta algul on kümblusõpilaste ja vene kontrollrühma eesti keele oskus enam-vähem sarnane, siis kevadeks on need rühmad teineteisest sedavõrd kaugenenud, et neid on juba raske teineteisega võrrelda (Uurimus 2001: 2; Asser jt 2002: 18, 2003: 46 jj). Samal ajal pole märkimisväärt erinevust näiteks loodusõpetuse testi tulemuste vahel (vt joonis 5 ).

2. klassi lõpuks on keelekümblusõpilaste ja vene tavaprogrammi õpilaste eesti keele oskuse tasemete vahe juba nii suur, et edasine võrdlus ei ole enam mõttekas. Seetõttu 3. klassis vene kontrollrühmale eesti keele testi ei tehta.

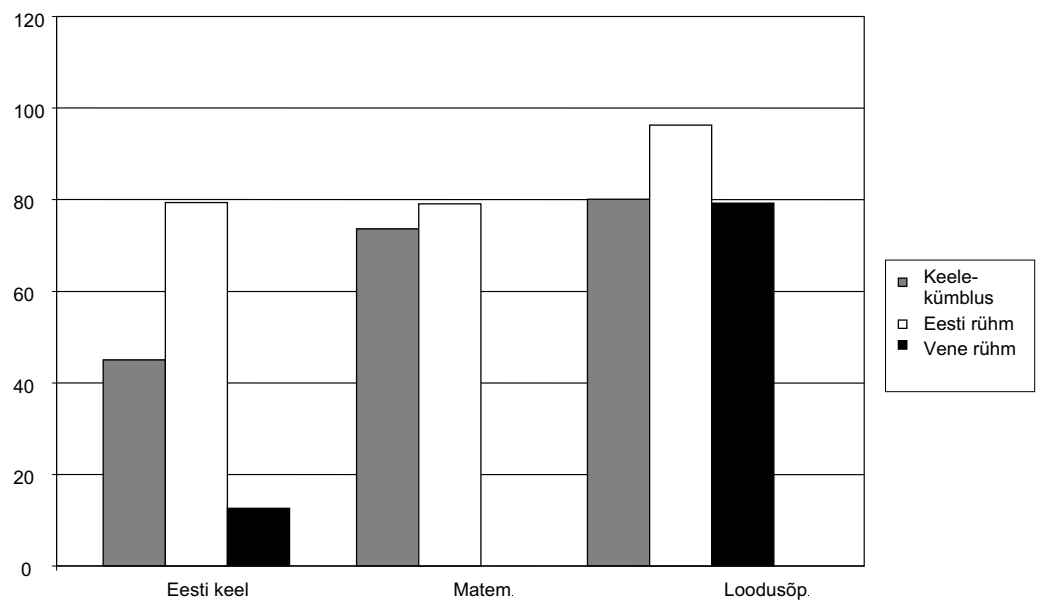

Joonis 5. 1. klassi keelekümblusõpilaste õppekavapõhise testi tulemuste võrdlus kontrollgruppidega (sooritusprotsent maksimumist) (Asser jt 2002: 18) 
2004/2005. õppeaastaga lõppes viieaastane varase keelekümbluse õpitulemuste ja lapsevanemate hoiakute uuring. Selle käigus on uuritud kõigi klasside õpitulemusi I kooliastmes 5 aasta jooksul kolme aastakäigu lõikes. Ainetestide tulemused kolme aasta kokkuvõttes näitavad, et õppimine teises keeles on õpilastele jõukohane ja eesti ning vene keele areng kulgevad ootuspäraselt heal tasemel (Asser jt 2005: 27). Viieaastase uuringu kokkuvõttena võib kinnitada, et varane täielik keelekümblus on konkurentsivõimeline haridusmudel, mis annab õppijatele eesti keele oskuse ja normikohase üldhariduse (Asser jt 2005: 63).

Lapsevanemate hinnang programmile on püsinud stabiilselt kõrgel tasemel. Programmi kõige õnnestunumaks komponendiks peetakse ülekaalukalt eesti keele õppe üldist korraldust ja selle eri aspekte ning õpilaste eesti keele oskuse arengut. Keelekümbluskooli valikul on enamik vanematest arvestanud lapse tulevase võimalusega omandada kõrgharidus Eestis. Vanemad valivad kümblusklassi valdavalt kolmel põhjusel: parim võimalikest valikutest (68\%), vene kooli traditsiooniline eesti keele õpetus ei rahulda õppijate vajadusi (60\%); laps ei oska eesti keelt (40\%). Õpilased on pandud keelekümblusklassi ootusega, et laps saab kvaliteetse hariduse ning seejuures saab selgeks nii eesti kui vene keele (Asser jt 2002: 12).

Hilise keelekümblusprogrammi uuring on kestnud kaks õppeaastat, mille jooksul on kirjeldatud programmi esimesi samme, kogutud alusandmeid esimese aastakäigu ettevalmistusklassi (6. klass) õpitulemuste kohta (Asser jt 2004, 2005) ja programmi esimese aasta tulemuste kohta (Asser jt 2005). Eesti keele testis edestas 6. klassi ettevalmistusrühm vene tavaprogrammi õpilasi ülesandetüüpide kaupa kõigis mõõdetud oskustes (Asser jt 2005: 47), mis näitab kümblusõpilaste eesti keele oskuse jõudsat edenemist juba programmi eelaastal.

Uurimistulemuste põhjal võib ka väita, et lapsevanemate ootused hilise keelekümblusprogrammi suhtes seonduvad eelkõige heade tulevikuväljavaadetega, mida seotakse võimalusega õppida edasi Eesti kõrgkoolides, ning eesti ja vene keele oskusega. Ligi 1/5 lapsevanematest leiab, et keelekümblus on hea ettevalmistus eesti õppekeelega kooli üleminekuks (Asser jt 2005: 58).

Kokkuvõtteks võib nentida, et keelekümblus on tõhus kakskeelse hariduse programm, mis on vene õpilaste ja nende vanemate hulgas kiiresti poolehoidu võitnud ja jõudsalt levinud.

Kuid programmiga haaratud õpilased moodustavad vene põhikooli õpilaste üldhulgast siiski veel vaid suhteliselt väikese osa. Mis puutub 2007. a kooliuuendusse, siis seda programm praktiliselt veel kuigivõrd mõjutada ka ei jõua. 2007. a kevadel lõpetavad põhikooli alles esimesed neli hilise kümblusprogrammi klassi, mis alustasid õpet 2003. a sügisel. 2008. ja 2009. a on aga lõpetajaid juba poole rohkem. Lisaks lõpetavad 2009. a kevadel põhikooli ka juba esimesed varase täieliku kümblusprogrammi õpilased. Edasine mõju oleneb sellest, kui ulatuslikult ja järjepidevalt kümblusprogramm tulevikus laieneb, kui hästi tal õnnestub kvaliteeti tagada ning millisel määral ta suudab tavaprogrammiga koole metoodika arendamisel kaasa haarata. 


\section{Koordineerimata eestikeelne aineõpe}

Reas koolides õpetatakse üht või mitut eestikeelset ainet ka omal algatusel, sooviga õpilaste eesti keele oskust edendada. Sisuliselt on sellisel juhul püütud riiklikku tavaprogrammi oma võimaluste ja oskuste kohaselt tõhusamaks muuta. Erinevalt keelekümblusest on siin ainete valik juhuslik, sõltudes konkreetse kooli huvist, võimalustest ja arusaamadest. Seetõttu ei saa kavandada ka kindlat ühist eesmärki ega määratleda tulemust. Sageli on eestikeelse aineõppega haaratud vaid üksikud klassid või ainult osa sama klassi õpilastest. Ainete valik on piiratud ja ühekülgne. Haridusstatistikast selgub, et need on valdavalt oskus- ja/või loovaineid, mille hulka kuuluvad sagedamini muusikaõpetus, tööõpetus, kehaline kasvatus, joonistamine. Harvem õpetatakse eesti keeles ka kodulugu, loodusõpetust ja ajalugu ning vaid üksikjuhtudel matemaatikat ja keemiat. 2004. a HTM-i tellitud Emori uuringu tulemused näitavad, et ainete valikul on lähtutud eeskätt lihtsuse põhimõttest. Reaal- ja humanitaarainete puhul oli peamiseks vastuargumendiks sisuline keerukus või liiga ulatuslik sõnavara. Seejuures ei ole ainete valikul arvestatud nende sisulist väärtust sõnavara mõttes ehk seda, milliseid aineid oleks mõttekas eesti keeles õpetada, lähtudes õpilaste eesti keele oskuse parandamise ja rikastamise eesmärgist (Emor 2004: 87-88). Tähtis on aga silmas pidada sõnavara ja väljendusoskuse igakülgset arengut. Vene kooli aineõpetajate arvamuse järgi peaks eestikeelse aineõppe kavad ja programmid olema kõikide koolide jaoks üheselt välja töötatud ja võrdselt kehtivad, mis tagaks põhikooli lõpuks ühtlase keeleoskuse ning sellega ka võimaluse üleminekuks ühest koolist teise (Emor 2004: 91). Siit järeldub, et soovitud eesmärgi saavutamiseks on eestikeelse aineõppe riiklik suunamine vältimatu. Küsitlusest selgub ka (samas: 62), et vaid väike osa (15\%) kõigist aineõpetajatest hindab olukorda positiivselt: üleminekuks on tehtud piisavalt ettevalmistusi ja üleminek peaks toimuma sujuvalt, ilma suuremate raskuste ja probleemideta. 60\% õpetajaist arvab, et on tehtud küll teatud ettevalmistusi, kuid üleminek toob tõenäoliselt kaasa raskusi ja probleeme. 25\% leiab, et tehtud ettevalmistused ei ole piisavad ja üleminek toob tõenäoliselt kaasa palju raskusi ja probleeme.

\section{Kokkuvõte}

Artiklis jõutakse järeldusele, et valdav osa vene koolidest ei ole piisavalt ette valmistatud selleks, et alustada 2007. a üleminekut eesti õppekeelega gümnaasiumile. Koolikorraldus ja riiklik õppekava ei taga vene põhikooli lõpetajatele eesti keele oskust tasemel, mis võimaldaks neil jätkata õpinguid eesti keeles. Riikliku tavaprogrammi järgi toimub kogu aineõpe vene keeles ja eesti keelt õpetatakse A-võõrkeelena üksnes eesti keele tunnis, mis aga ei võimalda saavutada põhikooli lõpuks vajalikku keeleoskuse taset. Taseme saavutamise vältimatuks eelduseks on eestikeelse aineõppe kasutamine, mis omakorda eeldaks eestikeelse aineõppe ühtseid riiklikke kavasid ja programme.

2004/2005. õppeaasta seisuga osaleb eestikeelses aineõppes umbes kolmandik vene põhikooli õpilastest ja veidi üle veerandi 7. klassi õpilastest. Õppeainete valik on aga valdavalt juhuslik, arvestamata nende mõttekust keeleoskuse aren- 
damise seisukohalt. Sellest erineb süsteemne, kuid piiratud levikuga kakskeelse õppe programm - keelekümblus, mida kasutatakse alates 2000. a tavaprogrammi kõrval alternatiivse võimalusena. Kuigi programm on head vastuvõttu leidnud ja jõudsalt laienenud, ei suuda see 2007. a kooliuuendust veel kuigivõrd mõjutada, sest vene põhikooli õpilastest vaid ca $4 \%$ on programmiga haaratud. 2007. a kevadel lõpetavad põhikooli alles esimesed hilise keelekümbluse 4 klassi, kokku umbkaudu 120 õpilast. Seega võib öelda, et 2004/2005. õppeaasta seisuga on vaid vähesed vene koolid ette valmistatud alustama 2007. a üleminekut eestikeelsele gümnaasiumiõppele.

Praeguse olukorra on tinginud peamiselt asjaolu, et üleminekut eesti õppekeelega gümnaasiumile ei ole riiklikult suunatud, et puudub seda reguleeriv tegevuskava. Kooliuuenduse tulevik sõltub sellest, kui jõudsalt suudab keelekümblusprogramm laieneda ja vene põhikooli arengut üldiselt mõjutada ning milliseid meetmeid riik protsessi suunamisel rakendab. Eeskätt tähendaks see koolikorralduse muutmist. Et õppekeelte regulatsioon vastaks põhiseadusele, vajavad kriitilist ülevaatamist ja korrastamist haridusseadus, põhikooli- ja gümnaasiumiseadus ning sellel põhinev riiklik õppekava.

\section{Kirjandus ja allikmaterjalid}

Ained 2005 = Eesti keeles õpetatavad õppeained vene õppekeelega üldhariduslikes päevase õppevormiga koolides ja klassides 2004/2005. AS Innove Hariduse ja Tööhõive Seirekeskuselt e-kirjaga 22.02.2005.

Asser, Hiie 2001. Muutused vene kooli õpilaste eesti keele oskuses 1994-1999. Kommenteeritud andmebaas. Tartu.

Asser, Hiie 2003. Varajane osaline ja täielik keeleimmersioon eesti muukeelse hariduse mudelitena. Dissertationes Pedagogicae Universitatis Tartuensis. Tartu: Tartu Ülikooli Kirjastus.

Asser, Hiie; Küppar, Maire; Kolk, Peeter 2002. Eesti keelekümblusprogramm. Uurimisrühma aruanne 2001/02. Tartu.

Asser, Hiie; Küppar, Maire; Kolk, Peeter 2003. Eesti keelekümblusprogramm. Uurimisrühma aruanne 2002/03. Tartu.

Asser, Hiie; Küppar, Maire; Kolk, Peeter 2005. Keelekümblusõpilaste õpitulemuste ja lapsevanemate hinnangute uuring. Uurimuse aruanne. Õppeaasta 2004/05. Tartu. http://www.kke.ee/index_bin.php?action=REF\&fname=547_Keelekumbluse_ uuringu_aruanne_2005.doc (8.01.2006).

Eelnõu 2005 = Põhikooli- ja gümnaasiumiseaduse ning erakooliseaduse muutmise seadus. Eelnõu 06.12.2005. http://eoigus.just.ee/?act=6\&subact=1\&OTSIDOC_W=118485 (23.01.2006).

Eelnõu 2005a = Seletuskiri "Põhikooli- ja gümnaasiumiseaduse ning erakooliseaduse muutmise seaduse” eelnõu juurde. http://www.riik.ee/saks/ikomisjon/programm. htm (20.03.2005).

Eelnõu 2005b = Vabariigi Valitsuse 25.01.2002. a määruse nr 56 "Põhikooli ja gümnaasiumi riiklik õppekava" muutmine. http://eoigus.just.ee/?act=6\&subact=1\&OTSIDOC_W $=118485$ (23.01.2006).

Ehala, Martin; Saarso, Kristi; Vare, Silvi; Õispuu, Jaan 1999. Eesti keele suhtluslävi. Treshold level for Estonia. Toim M. Ehala, S. Liiv. Council of Europe Publishing.

EKA 1997 = Eesti keel (vene õppekeelega koolile). RT I 1997, 37/38, 573. 
EKAS $=$ Eesti keele arendamise strateegia 2004-2010. Haridus- ja Teadusministeerium. Eesti keelenõukogu. Tartu, 2004.

EKR = Euroopa keeleõppe raamdokument: õppimine, õpetamine ja hindamine. Tööversioon. Haridus- ja Teadusministeerium. Keeletalitus. Tartu, 2003.

EKS $=$ Erakooliseadus. RT I 1998, 57, 859.

Emor 2004. Eestikeelne aineõpe vene õppekeelega koolides: hetkeolukord ja vajadused. November-detsember 2004. http://www.hm.ee/ (19.01.2006).

Hausenberg, Anu-Reet; Kikerpill, Tiina; Rõigas, Maia; Türk, Ülle 2003. Keeleoskuse mõõtmine. Käsiraamat. Tallinn: Tea Kirjastus.

HS = Eesti Vabariigi haridusseadus (1992). RT I 2005, 65, 498. https://www.riigiteataja.ee/ ert/act.jsp?id=968165 (14.03.2006).

Kikerpill, Tiina; Türk, Ülle 2005. Eksperthinnang eesti keele kui teise keele põhikooli lõpueksamile aastatel 2002-2004. Tartu 2005. Käsikiri Haridus- ja Teadusministeeriumi keeletalituses.

Koolieelse lasteasutuse seadus. RT I 1999, 27, 387.

KS (1989) = Eesti NSV Keeleseadus. Eesti Teaduste Akadeemia. Keele ja Kirjanduse Instituut. Tallinn: AE Signalet.

KS = Keeleseadus (1995). RT I 2005, 1, 1. https://www.riigiteataja.ee/ert/act.jsp?id=835593 (14.02.2006).

PGS 1993 = Põhikooli- ja gümnaasiumiseadus. RT I 2002, 64, 393.

PGS 1997 = Põhikooli- ja gümnaasiumiseaduse $\S 52$ muutmise seadus. RT I 1997, 69, 1111. PGS 1999 = Põhikooli- ja gümnaasiumiseaduse $§ 9$ muutmise seadus. RT I 1999, 79, 730.

PGS 2000 = Põhikooli- ja gümnaasiumiseaduse §-de 9 ja 52 muutmise seadus. RT I 2000, 33,195 .

PGS 2002 = Põhikooli- ja gümnaasiumiseaduse muutmise seadus. RT I 2002, 34, 205.

Phare $2002=$ Muukeelse elanikkonna eesti keele õppe vajadusuuring. Sihtrühma ootused ja eelarvamused uue eksamisüsteemi suhtes. Soovitused kommunikatsiooniprogrammi arendamiseks. Euroopa Liidu Phare eesti keele õppe programm. Oktoober - november 2002. http://www.meis.ee/phare/new/ktmp/keeleoppe _aruanne_fin.pdf (veebruar 2004).

Ploom, Kristi 2005. Statistiline ülevaade õpilaste ja koolide arvust. - Ülevaade üldharidusest 2001-2005. Haridus- ja teadusministeerium. Üldharidusosakond. Tartu, 2005, 14-24. http://www.hm.ee/ (26.01.2005).

PS = Eesti Vabariigi põhiseadus (1992). RT 1992, 26, 349. http://wlex.lc.ee/list/ PS.htm\#p5o (15.02.2006).

Rannut, Mart; Rannut, Ülle; Verschik, Anna 2003. Keel. Võim. Ühiskond. Sotsiolingvistika ja keelepoliitika õpik. Tallinn: TPÜ Kirjastus.

Reinthal, Riina 2005. Muukeelse hariduse arendamise kava 2. e-kirjaga 05.04.2005.

$\mathrm{RP}=$ Riiklik programm "Integratsioon Eesti ühiskonnas 2000-2007". http://www.riik.ee/saks/ikomisjon/programm.htm (20.03.2005).

RÕK 1996 = Eesti põhi- ja keskhariduse riiklik õppekava. RT I 1996, 65-69, 1201.

RÕK 2002 = Põhikooli ja gümnaasiumi riiklik õppekava. RT I 2002, 20, 116.

Soll, Maie 2005. Ettevalmistus 2007. aastaks (eestikeelsele gümnaasiumiõppele ülemineku algus vene õppekeelega koolides). - Ülevaade üldharidusest 2001-2005. Haridusja teadusministeerium. Üldharidusosakond. Tartu. 106-109. http://www.hm.ee/ (26.01.2005).

Uurimus 2001 = Ülevaade 2000-2001 õppeaasta uurimusest õpilaste õppeedukusest ja vanemate hoiakutest. http://www.kke.ee/index.php?lang=est\&pages_ID $=46 \&$ menus_ID $=1 \&$ active_link_ID $=55 \&$ mark $=0$ (6.01.2006).

Vare, Silvi 1999. Eesti keele õpetamine vajab uuendamist. - Keelekümblus kui integratsiooni võti. Koost ja toim Silvi Vare. Haridusministeerium. Tallinn. 
Vare, Silvi 2004. Eesti keel vene koolis. Haridus- ja teadusministeerium. Eesti keelenõukogu. Tallinn: Eesti Keele Sihtasutus.

VKS = Vähemusrahvuse kultuuriautonoomia seadus (1993, RT I, 73, 1001). Kehtiv versioon: RT I 2002, 62, 376. https://www.riigiteataja.ee/ert/act.jsp?id=182796 (17.02.2006).

Volkova, Irina 2001. Eesti keele riigieksami ja ülikooli vastuvõtueksami tulemuste võrdlus. Juhendaja prof Anu-Reet Hausenberg. Seminaritöö. Käsikiri Tallinna Ülikooli eesti keele õppetoolis. Tallinn.

Ülevaade üldharidusest 2001-2005. Haridus- ja teadusministeerium. Üldharidusosakond. Tartu, 2005. http://www.hm.ee/ (26.01.2005). 


\section{ARE RUSSIAN-MEDIUM SCHOOLS READY \\ TO CHANGE OVER TO ESTONIAN AS A LANGUAGE \\ OF SECONDARY-LEVEL INSTRUCTION IN 2007?}

\section{Silvi Vare}

At present, the full programme of general education is available both in Estonian and in Russian. According to the Basic and Upper Secondary Schools Act ${ }^{18}$, however, in upper secondary schools the language of instruction is the Estonian language. Thus the law requires that from 2007 all local foreign-medium secondary schools have to begin a transition to Estonian as a language of instruction. ${ }^{19}$ By that time the school system and the national curriculum should guarantee that all graduates of basic school (forms 1-9) have the Estonian competence enabling them to continue their education in Estonian. The stipulated change of the language of tuition is necessary to improve the Estonian competence of the pupils of Russian-medium schools, thus fostering their integration in the Estonian community.

Of all pupils of Estonia 23\% attend Russian-medium schools. Most of them (ca 80\%) live in Tallinn or Eastern-Virumaa. The number of children directly affected by the school reform of 2007, i.e. the total number of pupils in Russianmedium grade schools today is 32510 .

According to the national curriculum, Russian-medium schools teach all subjects in Russian, while Estonian is taught as an obligatory first foreign language from the first form on. Such a segregative programme, however, does not enable a satisfactory Estonian competence. The national curriculum overlooks the fact that the necessary competence level cannot be attained without bilingual training in grade school. Thus, to improve the results of Estonian teaching a new, bilingually-oriented alternative approach called language immersion was adopted in 2000, drawing on Canadian and Finnish experience. About $4 \%$ of the pupils of Russian grade schools are involved. For them, at least half of the teaching takes place in Estonian. In their parents' opinion this is the best choice available. Unfortunately this does not concern the 2007 reform, as by that time around a mere hundred or so of "immersed" pupils will have finished grade school.

A number of schools have, on their own initative, included one or more Estonian-medium subjects in their curricula. The choice, however, has been occasional, without considering linguistic efficiency. Evidently for the sake of simplicity, the most frequently chosen subjects are music, handicrafts, gymnastics, and drawing. The teachers of Russian schools believe that a uniform level of Estonian competence could be achieved only in case unambiguous and equally obligatory programmes were enforced for all schools.

The conclusion of the article reads that most of the Russian-medium schools are not sufficiently prepared for the 2007 reform. The main reason lies in the fact that the stipulated transition has not been shaped by state organs.

\footnotetext{
${ }^{18}$ Basic education is the minimum compulsory general education (forms 1-9). Secondary education is based on basic education. General secondary education is acquired in upper secondary school, the upper secondary level spans forms 10 through 12 .

19 This means that at least $60 \%$ of the teaching should be done in Estonian.
} 
Keywords: language teaching system, bilingual education, language immersion, transition to Estonian as the language of instruction

Silvi Vare (1939), filoloogiadoktor, Eesti Keele Instituudi vanemteadur. Peamised uurimisalad on eesti keele sõnamoodustus ja eesti keele kui teise keele õpetamine, eeskätt selle riikliku korraldamise aspekt. Grammatikauurijana on käsitlenud nimisõna- ja adjektiivituletust, liitverbide problemaatikat, tagasimoodustust ja konversiooni. Deskriptiivse eesti keele grammatika üks autoreid. Keeleõppepoliitikat puudutavates kirjutistes on vaadelnud kakskeelse õppe erinevaid viise, analüüsinud muukeelsete õpilaste eesti keele oskuse taset ja seda mõjutavaid probleeme, keeleõppekorralduse küsimusi. Eraldi trükistena on ilmunud "Lähtekohti eesti derivatsiooni käsitluseks" (1979), "Nimisõnaliited tänapäeva eesti kirjakeeles" (1981), "Omadussõnaliited tänapäeva eesti kirjakeeles" (1984), "Eesti keele grammatika" I-II (1995, 1993, kaasautor), "Eesti keele suhtluslävi" (1997, kaasautor), "Eesti keel vene koolis" (2004).

Silvi.Vare@eki.ee 